\title{
Urban Waterfront Development for Designing Space in Coastal Cities
}

\author{
Amany A. Ragheb*, Rasha A. EL-Ashmawy \\ Department of Architectural, Faculty of Engineering, Delta University for Science \& Technology, Gamasa 11152, Mansoura, \\ Dakhliya, Egypt
}

Corresponding Author Email: amany.ragheb@ deltauniv.edu.eg

https://doi.org/10.18280/ijsdp.150311

Received: 27 November 2019

Accepted: 23 February 2020

\section{Keywords:}

city, costal, Gamasa, Mediterranean sea, urban development, waterfront

\begin{abstract}
This study aims to represent the important of using the waterfront for the development cities as early commerce and transportation. It explores the development process of a unique and famous waterfront area, analyses the effects of water as a planning element in urban area to give a perspective on the waterfront development. Gamasa as a case study missed this concept of using the waterfront for development although has a long waterfront in the Mediterranean Sea. It is absence of any obstacles (social conflict, land ownership, etc.) in the design/development process. It is used the mode categories of urban waterfront transformation as a tool for conservation, redevelopment and development. These led Gamasa to be a highly potential area as a significant area to be engaged in planning and development agencies. The output of planning solutions leads to increase in amusement parks which are directly associated with the sea and the variety of activities in these parks contribute greatly to the attractiveness to the site. And give a perspective on the waterfront development and discusses the principles of successful waterfront developments to be a guideline for Gamasa city waterfront developments.
\end{abstract}

\section{INTRODUCTION}

Waterfront means the piece of urban attached to a Sea, river, lake, harbor, etc. It means the area of city in shortest contact with water $[1,2]$.

Waterfront areas should be characterized by a full activity of port infrastructures that is well-defined as a large area of communication between urban expansion and water [3].

Waterfront is the 'front door' of any city. Human settlement has grown out at the mouth of seaworthy rivers, on bays, at key points along rivers and waterways of the sea. There was a close relation between the waterfront and the city as early export and transportation were water related. Water has an important significance in different urban cultures. Urban waterfront development is an area of interest for planners, urban designers, environmentalists, decision-makers, sociologists, politicians, and developers including the community. Waterfront development can include any combination of different land uses. Waterfront projects can be new projects or re-developments of existing waterfronts into new places $[4,5]$.

The shape of the shoreline along with the cities site are the most important impacts that affect city-water links which benefit from extended waterfronts along a short distance into to the city center. Extended waterfronts raise the opportunity of public spaces to be established on the waterfront and of these linked to other vicinity public spaces [6-8].

Waterfront development does not only focus on industrialized uses, such as industrial ports, but it focuses on recreational and tourism-oriented purposes as well. It is concerned with a diversity of uses that can take place along a waterfront, carrying in as many interests as possible to the waterfront. For example, due to environmental, public safety and security reasons, it may not be suitable to locate a public park and residential neighborhood within the same zone as an industrial port. It should be concerned by other factors such as environmental characteristics of this area and the political, resource, climatic, and social contexts that has no one solution for all [5].

The study of urban waterfront improvement in a variety of places around the world clearly indicates a wide variety of chances for improvement and other design methods. In each case, some features such as the kind of uses, range of improvement work, public and private participation act as a distinctive reflection of the waterfront's location, jurisdictional structure and urban context. However, certain features are common in those successful waterfront improvements $[1,2]$.

The objectives of this manuscript focus on the developing process of waterfronts in Gamasa as a coastal city to cover all its activities as a large area of communication between urban development and water. This depends on the study of the features of Gamasa city and the shore shape for Gamasa city waterfront improvement. This study is based on the concepts of waterfront improvement. It explores the development process of a unique and famous waterfront area, analyses the effects of water as a planning element in urban area to give a perspective on the waterfront development, and discusses the principles of successful waterfront developments to be a guideline for Gamasa city waterfront developments. 


\section{THEORITICAL CONCEPTS OF WATERFRONT DEVELOPMENT}

Urban waterfront redevelopment has been a 'fashion' in big cities around the world in the recent years. Urban waterfront once neglected areas became the focal points for social, recreational and economic activity. Cities throughout the world have been ambitiously redeveloping or reclaiming their waterfronts for a variety of uses [1, 2, 9].

Since the mid-1970's, major and minor waterfront cities have greatly benefitted from the renewal of their urban waterfronts which is not only concerned with the eye-catching destinations but also with tourists and local inhabitants alike. The old harbor-front has been replaced by an extension of the central business district's (CBD) retail and entertainment functions which has started to occupy its previous place.

The transformation of urban waterfront can be taken either as an extension of the central business district, its activities, and amenities or as a "unique district" where activities and amenities derived from the contiguity to navigable Urban waterfront development. The development countries like USA, UK and Canada mainly consist of the conservation/ redevelopment of the existing or abandoned (decayed) areas whereas in land hungry countries like Singapore, Japan and Hong Kong are characterized by reclamation and new development on the land [1,2]. Urban waterfront development aims for both cases at the integration of diverse urban waterfront spaces and experiences, linkage with the existing city fabric, development of a responsive form to the site's context and a livable neighborhood with clear identities [10].

\subsection{The effects of water element in urban areas planning}

There is a balance between nature and social life for a sustainable improvement of cities. Urban natural water elements contribute greatly to the formation of this balance. Water is considered to be a major factor in the planning process to meet the human physical and psychological needs. In addition, it provides the existing environment with several in aesthetic and functional features. The aesthetic effects include visual, audial, tactual and psychological features [11].

The visual includes:

- Relaxation, moving water adds liveliness and enjoyment to a space.

- Motionless water produces the mirror effect in the place

- Reflection element through the optical features

- Motion and peacefulness factors

- Sense of widening.

The audial include:

- Continuity of life, vibrancy and joy,

- Stagnant water creates a sense of serenity

- Moving water adds liveliness and creates a music effect.

The tactual include:

- Fall dropping to surface

- Receiving wet with stamping water of waterfall

- Being totally underwater in pool, lake or the sea

- Diving into the water is a kind of escape from the world. The psychological include:

- The sensitive result which is brain apparent

- Emotional reactions towards water which results from people's sprits

- Aquatic as an element which withdraws the continuity of life
- Sound and brightness of water makes people relax

According to the Önen, 2007 [12], the functionality of water in urban area planning process is an element the encompasses climatic relief, sound control, circulation and entertainment advantages such as swimming, fishing, boat, tour, entertainment, walking etc. The climatic conditions focus on the cool air by raising humidity in the environment. While the circulation focuses on walking around in the right direction and the intermission of sea to be as a spine task beside in the establishment of streets, parks... etc.

\subsection{Mode categories of urban waterfront transformation}

The Mode categories of Urban Waterfront Transformation include Conservation, Redevelopment and Development [3].

\subsubsection{Conservation}

It is a restoration of the historical characters and activities on the existing waterfront site. This type of plan aims at using the site of an old waterfront, which still exists even today [13] and restoring it for the people by making as many radical improvements as possible while withdrawing any disused facilities where necessary. Marseille and Venice are the examples of cities where good solid architecture has been repeatedly restored over the centuries and put to good use, Figure 1.
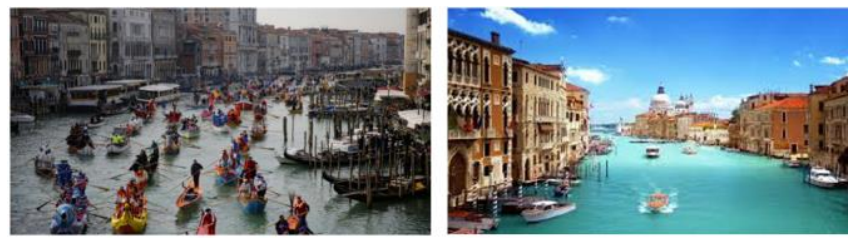

Figure 1. Venice is the example of cities where good solid architecture has been repeatedly restored. (Source:

https://www.google.com.eg/search?q=grand+canal\&hl.)

\subsubsection{Redevelopment}

It is a restoration of the existing activities for new activities as per demand. It is characterized by an attempt to revive harbors as important areas for urban life, converting the neighboring facilities for use in a different capacity [14], Melbourne and London's St. Katharine's Dock provides an example for this category Figure 2.
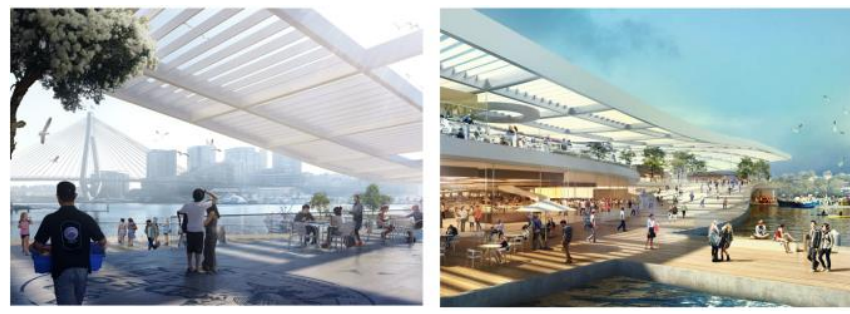

Figure 2. Melbourne provides an example for Redevelopment category (Source: https:www.designboom.com/wp-

content/uploads/2017/06/3XN-wins-competition-sydneyfish-market-designboom-011.jpg.)

\subsubsection{Development}

It is characterized by land reclamation $\&$ new development to meet the demand. It tries from the outset to create a waterfront which meets the present needs of the city by 
reclaiming land in such places where there has been no waterfront up till now Figure 3 Foster City, which has materialized at the southern end of San Francisco, falls into this category.

These well-documented developments, and others that have followed, have reassured city governments around the world that the urban waterfront can once again have a noteworthy part in the economic and social health of urban centers. They were even been claimed by Breen and Rigby (1994) [15]. to be a "worldwide urban success story". However, such developments have also been criticized as being expensive, time-consuming, often difficult to implement, sometimes controversial and not always in agreement with the needs or desires of residents [16].
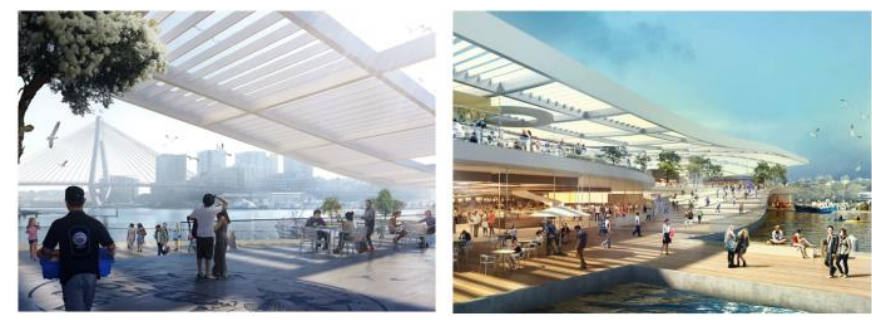

Figure 3. Hong Kong - a prime piece of Hong Kong waterfront land is coming up for development. (Source: https://urbanland.uli.org/wp-content/uploads/sites)

\subsection{Principles of successful waterfront developments}

The principles of successful waterfront developments are concerned with the Vision and Leadership, a theme which is define as the romantic aspect of the selected city. Contextualize that means the quality of any city is a relatively new element that has emerged as a significant component that describes traditional detail, character, function, public access and visual appearance.
The public access represents the concentration of people and public oriented activities to create the dynamic quality in the area. While the Visual character of the urban waterfront is determined by the composition of physical elements and viewer's response to those settings, it varies with the distance, elevation and movement of the viewer's [8].

\section{GAMASA AS A CASE STUDY}

Gamasa is located along the costal shoreline of the Mediterranean Sea, Egypt. It is a part of the Daqahliya Governorate. Gamasa is one of the in Dakahlia governorate which is considered as a direct link between the East Delta (Suez Canal Region), Central and West Delta. It has been assisted by the presence of many bridges along the Nile Damietta branch with a good road network Figure 4 . The city of Gamasa is bordered to the north by the Mediterranean Sea and from the south by areas of sand formations, marshes and agricultural areas, to the west is the city of Baltim, about 50 $\mathrm{km}$ away, to the south is the city of Sherbin which is about 35 $\mathrm{km}$ away and the city of Cairo which is about $35 \mathrm{~km}$ away.

The coastal city of Gamasa is characterized by clean sea, low humidity, and soft sand. The western range of Gamasa beach is stabilized due to highs and dunes that have helped protect this part of the coast from erosion. The beach of Gamasa is composed of bays in the shape of a crescent, which makes them good resorts depending on the degree of concave of the crescent shape. Unfortunately, negligence and failure to maintain the aesthetic image have affected the nature of the tourist city.

As the building city Figure 5 has high architectural style, the passage of the international coastal road separates the tourist and administrative residential area from the industrial zone, links the city to the rest of the northern governorates and makes it easy to reach.

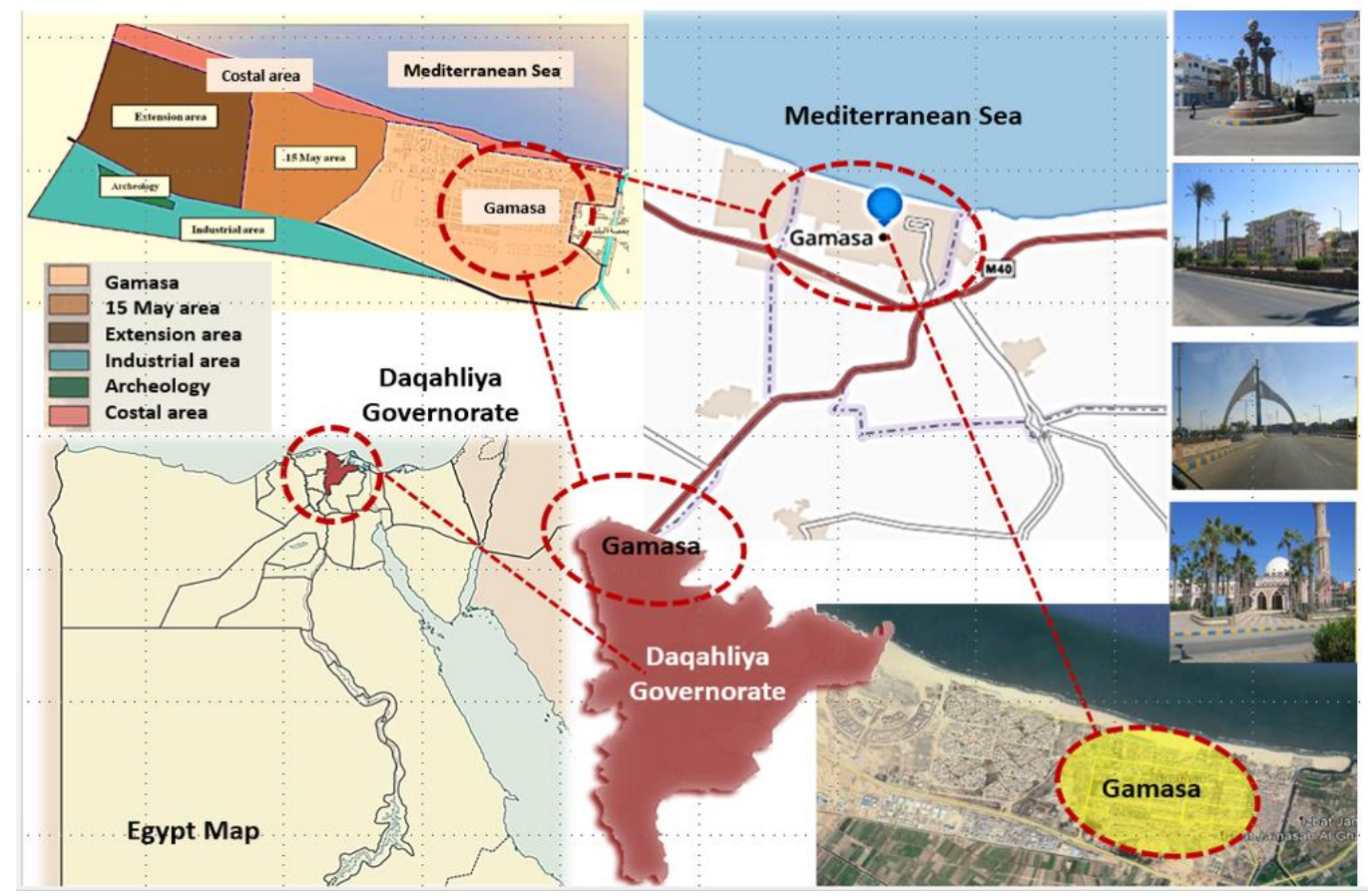

Figure 4. Gamasa is located along the costal shoreline of the Mediterranean Sea, Daqahliya Governorate, Egypt (Researches) 


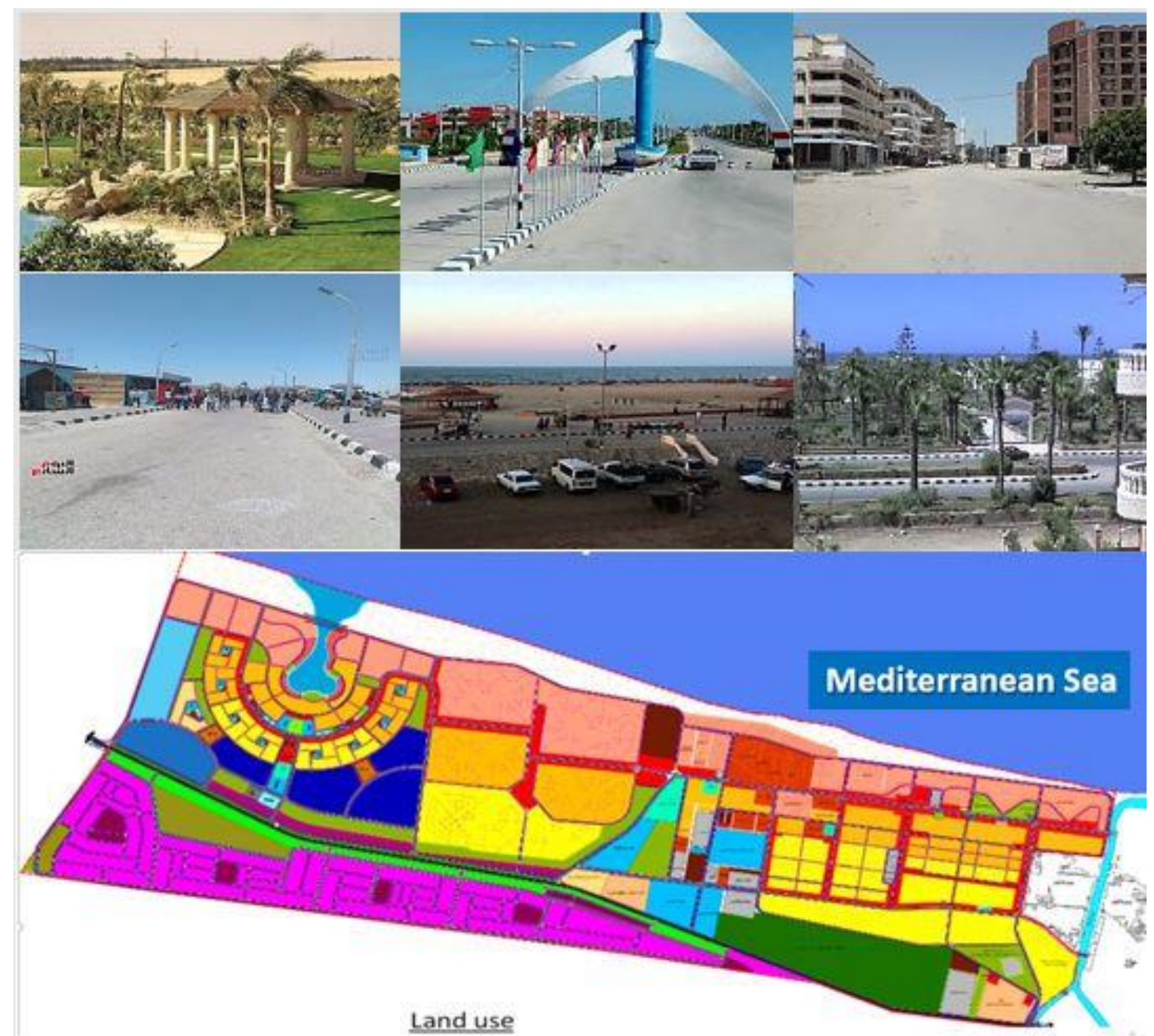

\begin{tabular}{|c|c|c|c|c|c|}
\hline \multicolumn{2}{|c|}{ Housing } & Mealth services & Social and cultural services & Industrial zone & Other uses \\
\hline & tourint & 0 On a neigheorhsed levet. & An a neighborhood level. & Industrial zone & radio and television beascksiting \\
\hline & $\begin{array}{l}\text { Above } \\
\text { Fronomis }\end{array}$ & On the Community leveh. & On the Community level. & Industrial Zone Services & es and ingthyes \\
\hline & Etonomic & 660 As the vector level. & At the sector level. & Facilities & the pribon servike \\
\hline & $\begin{array}{l}\text { Workers } \\
\text { Comp areas }\end{array}$ & & Recreational and sports services & Religious services & n areas and parks \\
\hline & Seach Campa & pus $(200 \mathrm{~m})$ & Mearby garden & Religious services & dentrial Lake \\
\hline & Fevest trees & & [D] Nelghborhoot Garden & 2 tielicisus serviket & fonal Rous Servikes Area \\
\hline$=-7$ & Proposed ab & ban suese & {$[0]$ routh and Cub Centre } & 2 On a neighborhood level. & pie vilage \\
\hline$=-7$ & & ban space & [0] Spents Seadum & On the Community level. & of amtiquities \\
\hline Educ: & cation service & & Commercial services & An the sector leved. & lierarchy Roads \\
\hline & Baric educati: & tion schooks & & Publlic services & $\begin{array}{l}\text { International Coestal Road } \\
\text { Main Roed } 36 \mathrm{~m}\end{array}$ \\
\hline$\bullet$ & Bask educath & tion (9 years) & $\begin{array}{l}\text { On neigtberhood. } \\
\text { On the city. }\end{array}$ & Dublk vervices & Main acerezator Road $24 \mathrm{~m}$ \\
\hline$\infty$ & Genecal vecor & endary education & commertial odminiatrative & Security services & Sub road azerezator $24 \mathrm{~m}$ \\
\hline 60 & Technical seco & cendary esucation & Commercial hubs & I security renvices & Proposed bridge \\
\hline & & & Deach servike wes & & International Coastal Roud Cam \\
\hline
\end{tabular}

Figure 5. Ministry of Housing, Utilities and Urban Communities, General Authority for Urban Planning, "Master Plan for The City of Jamasa", 2005

All these features make Gamasa city a tourist attraction for which the Egyptian government required development to be put on the map of Egypt tourism. The study evaluated all the elements required for the coast development of this site. In addition, there must be special conditions to cover the investment needs, which achieve a remarkable economic prosperity. This is done by giving the beach a distinctive architectural character and creating a strong image to stay always in the memory of the tourist along with the harmony of the facilities with the natural components of the site.

\section{DESIGN CRITERIA FOR GAMASA WATERFRONT PLANNING}

The analysis of the case study indicated a new relationship between the city and its water. The positive elements of the site, the water, and the view and leisure facilities are utilized 
to establish a new sort of everyday life. Gamasa city acts as an attraction point for the people as it is located by the water. The waterfront is enriched by the public open spaces such as green area and broad pedestrian walkway with central recreational and leisure activities zone. The range of improvement is human size, mainly the pedestrian network system. The waterfront zone is completely devoted to public activities such as restaurants and amusement centers.

For an effective waterfront improvement, it is advisable to follow a strategy that takes public sector priorities and responsibility into consideration. Waterfront improvement is believed to be an opportunity for economic progress. Collaboration between private and Government agencies partaking the risks and financial responsibilities will become more dominant in future waterfront improvement.

It is necessary to reconsider landscape and facilities, contextual, environmental, functional, formal and technological criteria in the process of designing the waterfront plan. These criteria were later figured out during the process of design decisions-making. These criteria include previewing the aspired future environmental outcome and the spreading of the project sustainable design features.

The basics of sustainable planning and environmental design for waterfront improvement of Gamasa could be summarized in the following topics:

\subsection{Vision and Leadership}

Waterfront improvement need clear vision and leadership for successful implementation.

- It should be beyond a physical concept to embrace living and working relationships, lifestyles and aspirations.

- It should have clear aims and objectives and should integrate the physical, social and economic elements in a way that strikes a careful balance between human needs and those of the market.

- The plan should clearly address finance, land acquisition, land use, control, phasing, design standards and marketing.

- Community involvement helps to implement many waterfront projects.

- The combination of political and social forces should necessitate immediate action, recognizing that cities must be developed with committee leadership.

\subsection{Contextualize}

The contextualize quality of any city is a relatively new element that has emerged as a significant component that describes traditional detail and character.

- A master plan has been developed to establish a welladjusted relationship with the topography, landscape, wetland, sea water, heritage sites and urban improvement features Figure 6.

- It provides the framework for the design approach applied in urban conditions.

- It analyses the existing qualities of streets, topology, fabric, and facades.

- Understanding the concept of the context is fundamental to coherent design and consistent strategies.

- Urban design, the critical combination of general notions of urbanism and specific concepts requires an expanded effort and a different process for designing a building.

- Urban space in different shape and size shall be well interconnected and best appreciated by

- Moving from one space to another Figure 7.

\subsection{Public access}

Urban waterfronts are the magnets and the people are generators.

- Concentration of people and public oriented activities create the dynamic quality in the area.

- The space is realized as a resource only when it can be enjoyed by the public Figure 8 .

- It must be open to view and easily approachable.

- Fully accessible waterfront (except where safety is involved) should be the goal in all waterfront undertakings.

- Visual access to the waterfront edge is as important as physical access.

- Economically speaking, people of all class and family types should have the capacity to access the waterfront for both housing and amusement purposes. Several public oriented activity places coupled by pedestrian circulation system can improve the waterfront area to become more stimulating and energetic thus supporting the area's security Figure 9.

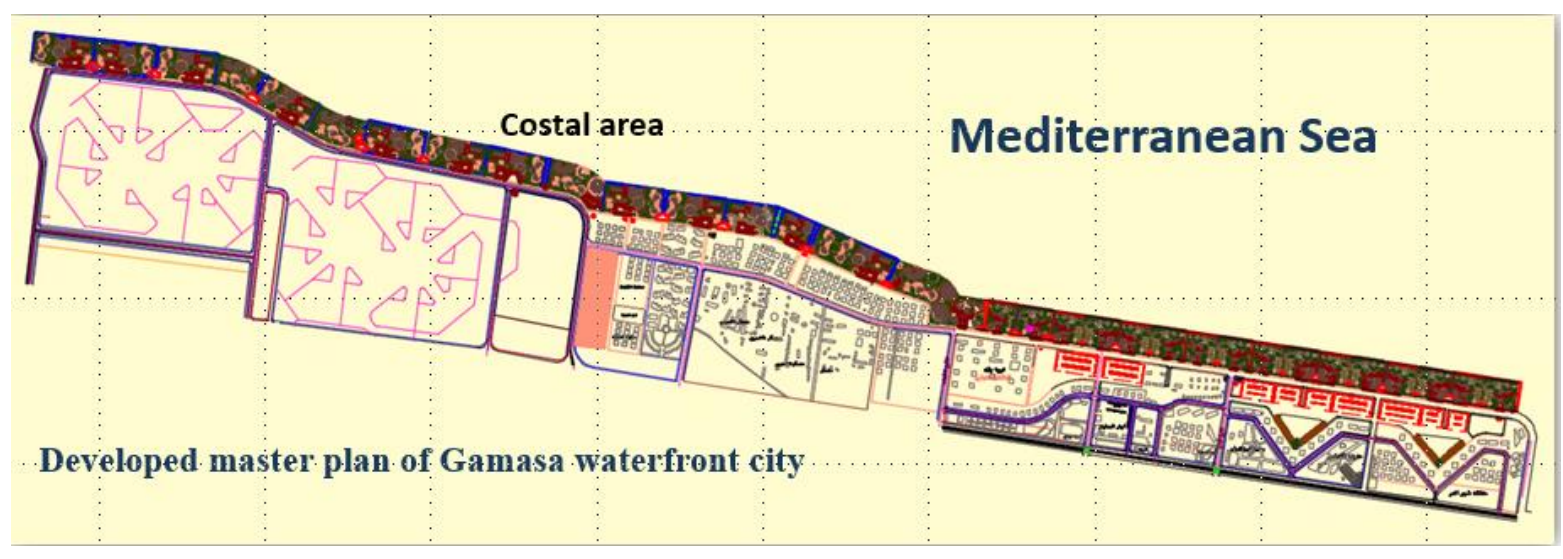

Figure 6. Developed master plan of Gamasa waterfront city 


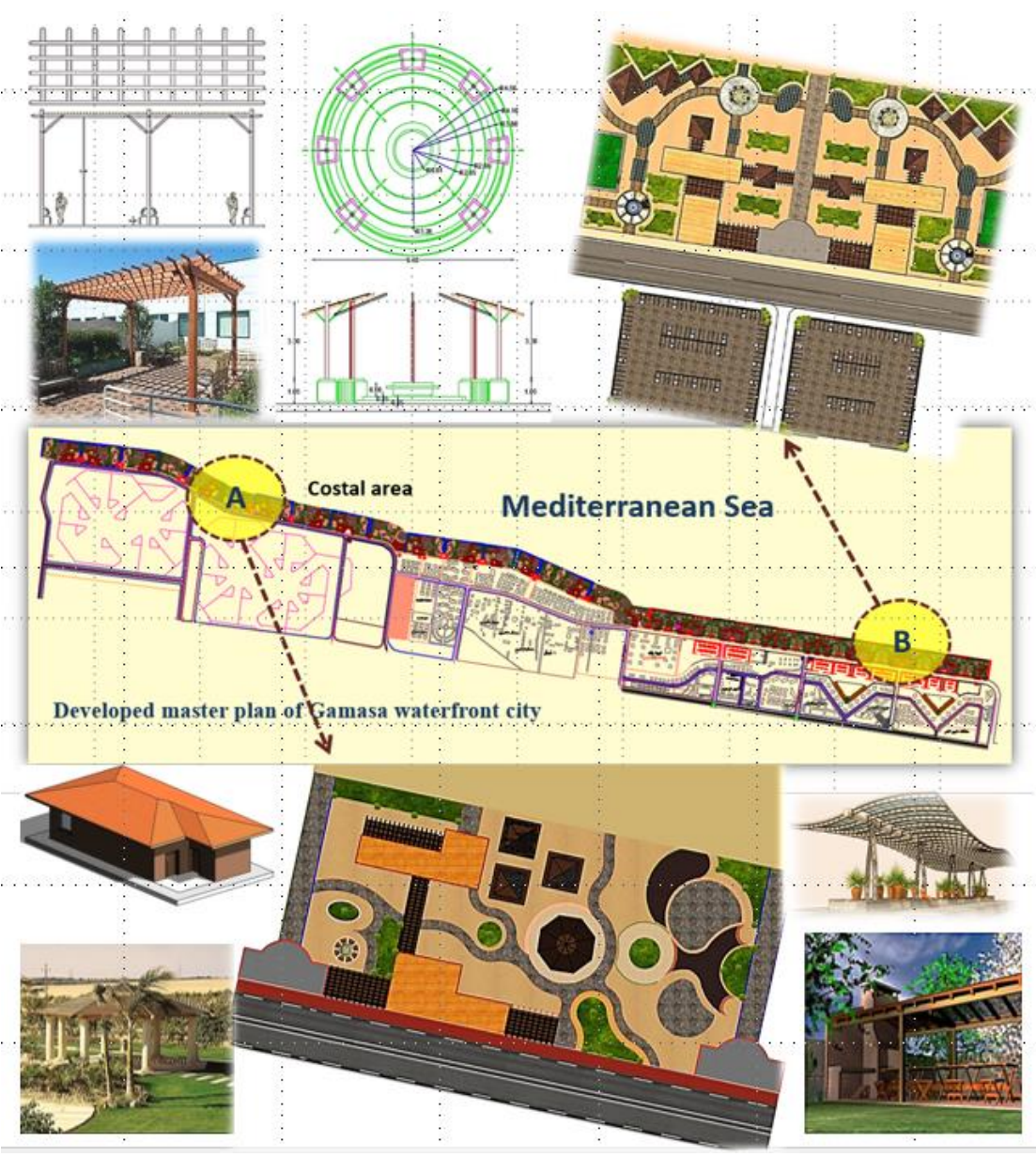

Figure 7. Urban space in different shape and size of Gamasa waterfront city

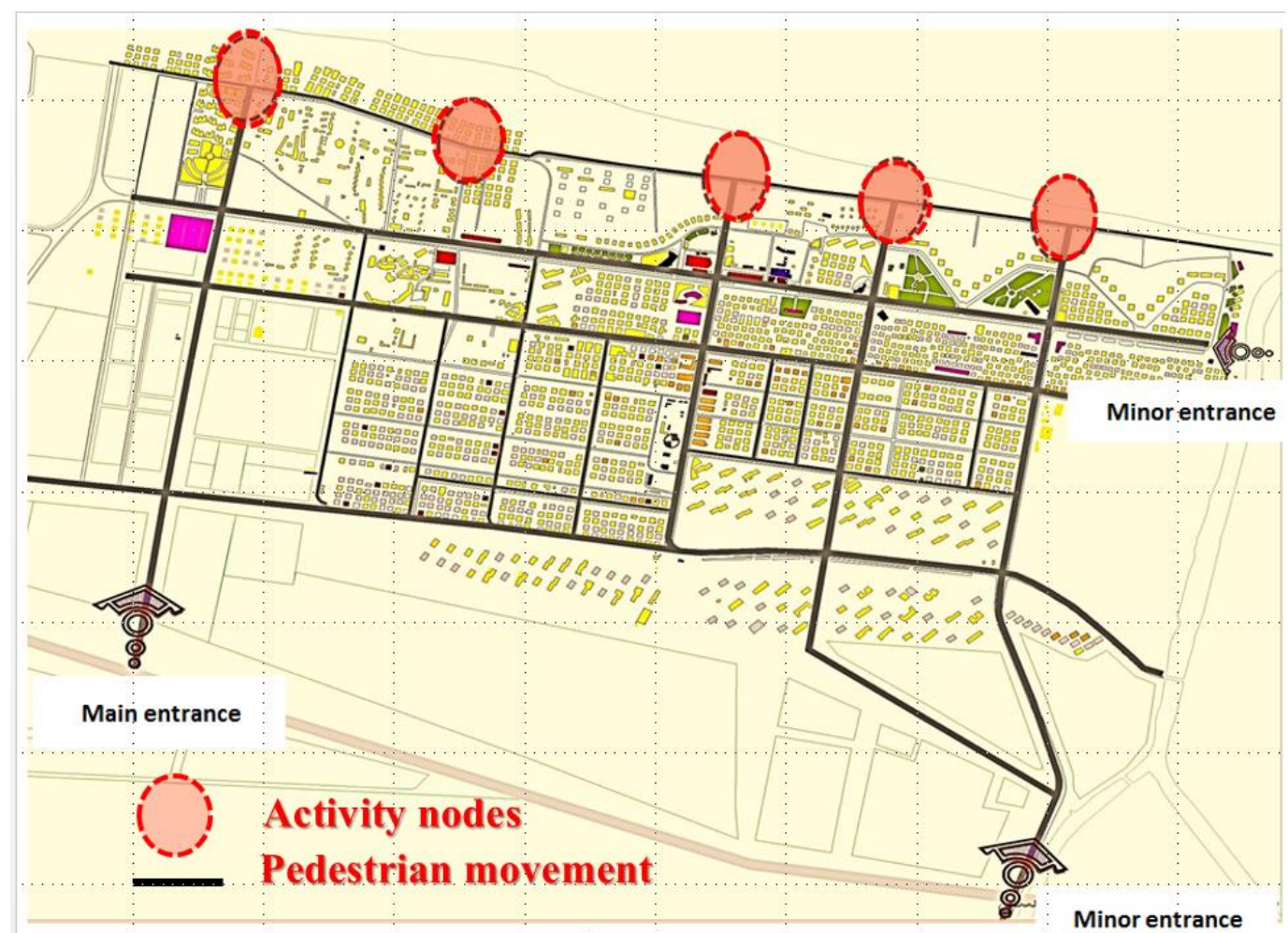

Figure 8. Various public oriented activity nodes connected by pedestrian movement 

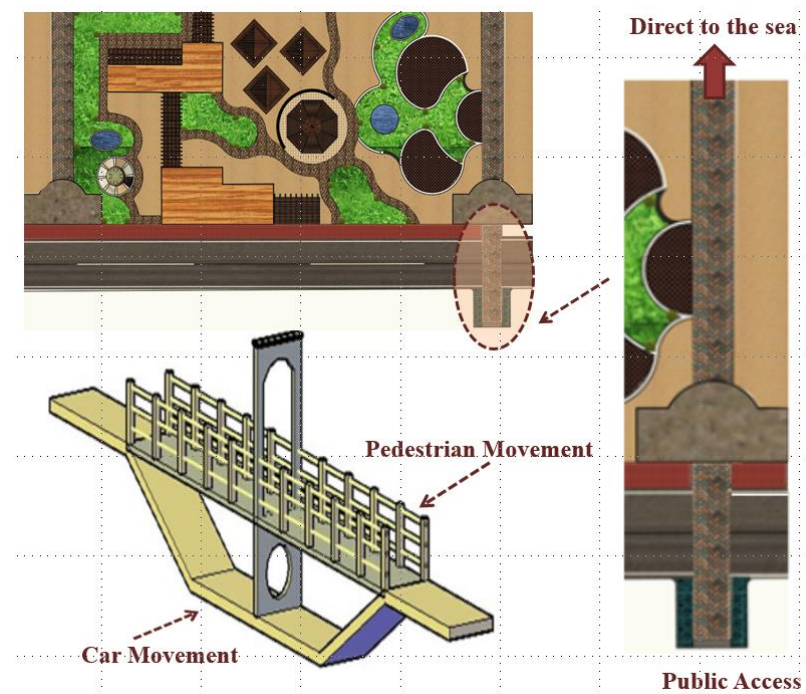

Figure 9. Various public oriented activity nodes

\subsection{Function}

The success of any waterfront improvement depends on how it functions well on all levels.

- Visitors' overall experience at different level must be defined in sequence to make the waterfront development successful.

- The transportation linkage to the city Centre, circulation, pedestrian movement, parking capacity ... etc. should be considered in the design process.

- There should be a sequence of spaces that are set uniquely to function well.

- Private space and public space should be blend without invading privacy.

- It is designed to use for multipurpose function, e.g., an open space can work as a farmer's or fishermen's market in the morning, a flower boutique in the afternoon/a concert at night.

- The space should be designed for various age groups and disabled persons as well.

- Opportunities to eat, watch, or simply sit and relax are essential to a successful waterfront improvement.

- Commercial activities will be viable only if public access and public spaces are provided around them.

\subsection{Preservation of nature and resources}

Sustainable project should commit to the preservation of natural habitats and archaeological sites in addition to the minimization of waste, sewage, and noise while the maximizing of the use of renewable sources. Existing concrete tiles have been preserved and used to confirm the walkways that reach the sea directly Figure 10.

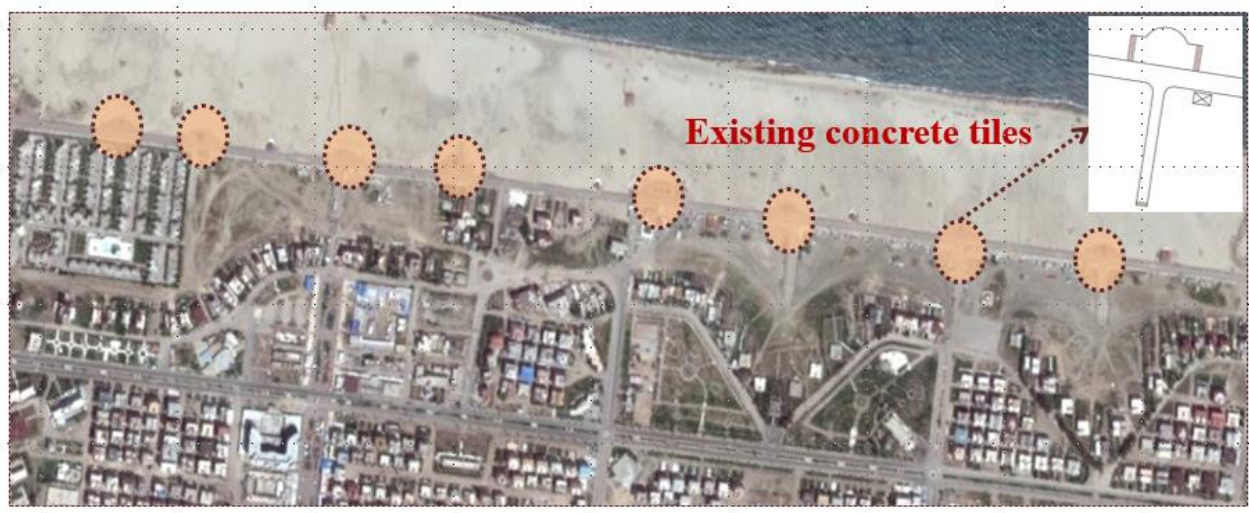

Figure 10. Existing concrete tiles have been preserved and used to confirm the walkways
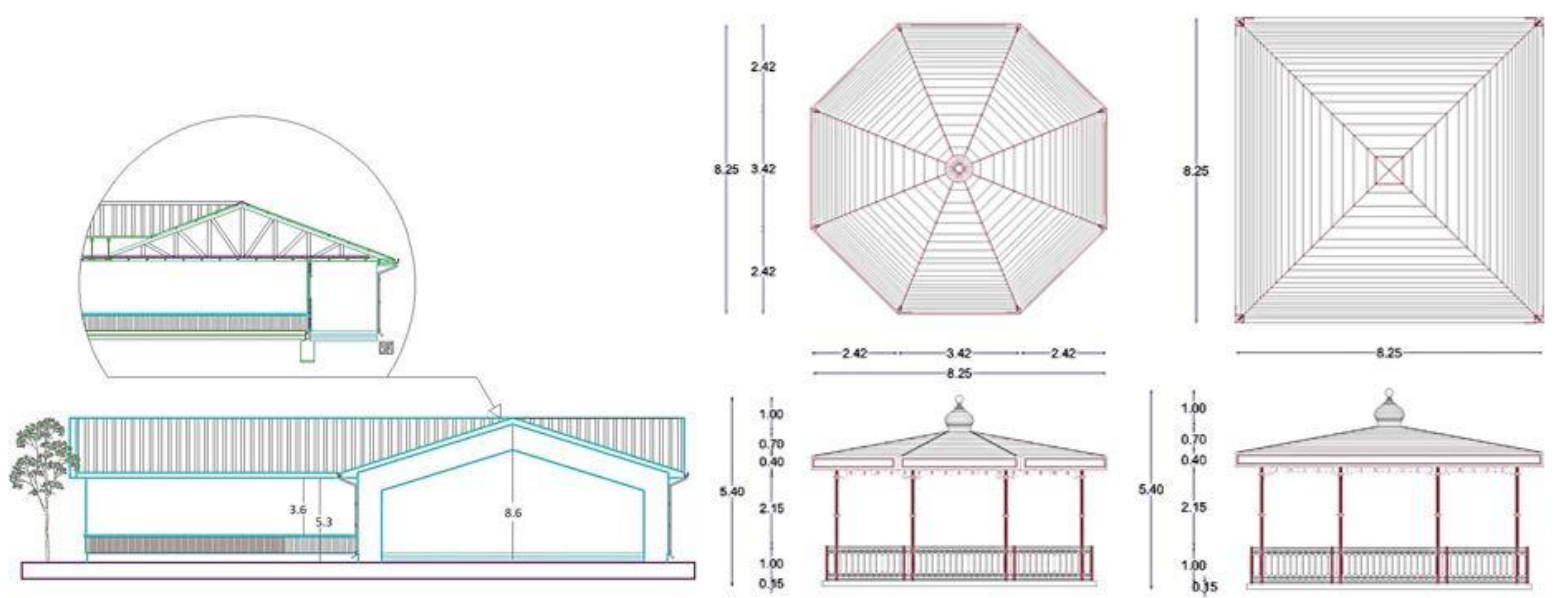

\section{Sweden Wood material}

Figure 11. Use of environment friendly technologies and materials 


\subsection{Use of environment friendly technologies and materials}

The sustainable planning design should be based in the local resources and traditional technologies adding comfort and environmental quality, for example we use Sweden wood which has high-evaporation, high-strength for erosion factors Figure 11.

\subsection{Linkages or touristic programs}

It is necessary to focus on the environmental circumstances of connections or touristic itineraries between various points of attraction, setting the scale and proportion of the man-made environment to the natural environment.

It was taken into account that the main design of the coast should be streamlined for the coordination lines so as not to give the impression that the parts are separated from each other, the design of the main roads and corridors with the rest of the landscape elements; trees and fences keep that excellence and variety to the coast.

\section{CONCLUSIONS}

The increase in amusement parks which are directly associated with the sea and the variety of activities in these parks contribute greatly to the attractiveness to the site. Planning solutions must be developed for the problem of the car roads, which separates the sea from the city. This will happen by changing the locations of the highways by keeping them away from the sea, by placing them in underground tunnels or by establishing foot bridges for pedestrians to cross these roads. All obstacles that block the vision should be removed from the shoreline whether they are dense trees, high fences or high buildings. The necessary coordination elements should be provided for the requirements of the recreational activity. Pedestrian paths, public squares and increasing the plant element should be redesigned. A suitable scenario should be developed to connect the recreational spaces overlooking the sea with each other with a clear network of pedestrian paths by applying the thought of urban axes.

\section{REFERENCES}

[1] Moretti, M. (2008). Cities on water and waterfront regeneration: The role of culture and events. Grundtvig, III Meeting Rivers of Change-river//Cities Wien, Austria. http://www.river-

cities.nazwa.pl/www/download/m.moretti_vienna2008. pdf.

[2] Moretti, M. (2010). Valorisation of waterfronts and waterways for sustainable development. International Scientific Conference about Poltva River RenewingLviv, Ukraine.

http://www.urbanproject.lviv.ua/php_uploads/data/articl es/ArticleFiles_84_Moretti_en, accessed on Oct. 5, 2012.

[3] Hou, D.Y. (2009). Urban waterfront landscape planning. Master Thesis, Blekinge Institute of Technology Karlskrona, Sweden, 53 p.
[4] Yassin, A.B., Eves, C., McDonagh, J. (2010). An evolution of waterfront development in Malaysia. Proceedings from the Pacific Rim Real Estate Society 16th Annual Conference (PRRES), pp. 1-17.

[5] Yassin, A.M., Ramlan, R., Razali, M., Najib, M. (2017). Assessing opportunities and challenges in waterfront development in Malaysia. Advanced Science Letters, 23(1): 511-513. https://doi.org/10.1166/asl.2017.7237

[6] Al Ansari, F. (2009). Public open space on the transforming urban waterfronts of Bahrain -the case of Manama city. Ph.D Thesis, Newcastle University School of Architecture, Planning and Landscape, Newcastle.

[7] Li, H., Chen, W., He, W. (2015). Planning of green space ecological network in urban areas: An example of Nanchang, China. International Journal of Environmental Research and Public Health, 12(10): 12889-12904. https://doi.org/10.3390/ijerph121012889

[8] Werthmann, C. (2007). Green Roof-A Case Study: Michael Van Valkenburgh Associates' Design for the Headquarters of the American Society of Landscape Architects. Princeton Architectural Press.

[9] Giovinazzi, O., Moretti, M. (2010). Port cities and urban waterfront: Transformations and opportunities. TeMAJournal of Land Use, Mobility and Environment, 2. https://doi.org/10.6092/1970-9870/123

[10] Zhang, W., Wang, F., Barchers, C., Lee, Y. (2017). The impact of transit-oriented development on housing value resilience: Evidence from the city of Atlanta. Journal of Planning Education and Research. https://doi.org/10.1177/0739456X18787011

[11] Permana, A.S., Astuti, W., Erianto. (2017) Waterfront development concepts in Indonesia from the perspective of urban planning and environmental sustainability. International Journal of Built Environment \& Sustainability, $\quad 4(3)$ : $146-155$. https://dx.doi.org/10.11113/ijbes.v4.n3.207

[12] Önen, M. (2007). Examination rivers' recreational potantial as an urban coastal space: Case study, eskişehir porsuk creek and istanbul kurbağalıdere. Master Thesis, Istanbul Technical University, Institute of Science and Technology, İstanbul, 204 pp.

[13] Ragheb, G., Ragheb, A.A., Ragheb, R.A. (2017). Adaptive re-use and sustainable development for existing historic buildings-case study: Buildings of racetrack horses in sporting club, Alexandria, Egypt. International Journal of Current Engineering and Technology, 7(4): 1523-1530.

[14] Ragheb, G., El-Shimy, H., Ragheb, A. (2016). Land for poor: towards sustainable master plan for sensitive redevelopment of slums. Procedia-Social and Behavioral Sciences, 216: 417-427. http://doi.org/10.1016/j.sbspro.2015.12.056

[15] Breen, A., Rigby, D. (1994). Waterfronts: Cities Reclaim Their Edge. McGraw-Hill, Inc., New York, 256 p.

[16] Tastsoglou, A., Vagiona, D. (2012). Urban waterfront regeneration: The Thessaloniki-Greece. Advances in Landscape http://dx.doi.org/10.5772/55759
Architecture. 